\title{
NECROLÓGIO
}

\section{DR. ELVIO SADUN}

O Dr. Elvio Sadun faleceu no dia 22 de abril próximo passado, no Hospital Walter Reed, de câncer no fígado, aos 56 anos de idade. Nasceu na Itália e depois naturalizou-se cidadão dos Estados Unidos; neste país, obteve o título de "master" em zoologia na Universidade de Harvard e PhD na Escola de Higiene e Saúde Pública de John Hopkins. Lecionou nas Universidades de Arkansas e Tulane e trabalhou no Serviço de Saúde Pública e no Instituto de Pesquisas Walter Reed. Foi perito da Organização Mundial da Saúde sobre doenças parasitárias e organizador do programa científico do Congresso Internacional de Parasitologia, em 1970. No Brasil, o Dr. Sadun era conhecido principalmente por seus trabalhos em imunologia, em es- pecial na malária, tripanosomose e esquistossomose. Esteve em nosso País em 1962, em uma Reunião de Debates sobre Doença de Chagas e em 1963, por ocasião do Congresso Internacional de Medicina Tropical. Sob sua inspiração, teve início o atual programa de pesquisas sobre esquistossomose, entre o Instituto de Pesquisas Walter Reed do Exército dos Estados Unidos e a Universidade de Brasilia. O Dr. Sadun foi autor de mais de 280 trabalhos sobre doenças parasitárias. Entre as instruções que deixou à sua esposa, senhora Iina Ottolenghi Sadun, estava a de comunicar seu falecimento à Sociedade Brasileira de $\mathrm{Me}$ dicina Tropical, da qual era membro honorário. com pesar que registramos 0 seu ób:to. 


\section{LIVROS}

DOENÇAS DO APARELHO DIGESTIVO (DISEASES OF THE DIGESTIVE SYSTEM) $2^{\text {a }}$ Edição, Blackwell Scientific Publications, por $\mathbf{S}$. C. Truelove e P. C. Reynell

A segunda edição desse já famoso livro, sem favor um dos melhores já escritas sobre a especialidade gastroenterológica, não modificou substancialmente sua forma.

Ao contrário, foram mantidas integralmente as características que o tornaram o companheiro inseparável do especialista, do internista e do estudante avançado, quais sejam, sua concisão e clareza incomuns.

Ele fol, no entanto, atualizado por inteiro, não tendo sido olvidado qualquer dentre os múltiplos desenvolvimentos que marcaram a década que medeia entre as duas ediçôes; estes incluem a análise e a sintese da gastrina, o estudo dos seus análogos químicos, os avanços extraordinários no conhecimento dos mecanismos em jogo na cólera, o reconhecimento e a compreensão da colite isquêmica, a descober- ta do antígeno Austrália, entre tantos outros desenvolvimentos, sem que o volume do livro tenha aumentado substancialmente, o que obtido mercê de cortes judiciosos e de um extraordinário poder de síntese.

A avaliação do livro pode ser facilmente realizada pelos leitores brasileiros através da leitura do capitulo 3, que tem o título sugestivo de "Acalasia do Cárdia e Doença de Chagas", na qual, em 13 páginas, contendo 4 ilustrações, os autores fazem o estudo crítico dos conhecimentos sobre a matéria não faltanđo mesmo, nas referências bibliográficas, nomes tão familiares para nós, como os de Kòberle, Penha e Ferreira-Santos.

É, pois, um livro que deve ser entusiasticamente recomendado a todos os que se interessam pela gastroenterologia e que deve ser lido integralmente, muito embora ele compita mesmo com os livros de referência, ao conter tudo o que estes contêm, a par da linguagem agradável e escorreita, da leitura fácil e do juízo crítico, presente a cada passo, o qual baseia-se em sólida e insofismável experiência. 